\title{
Maternal knowledge on curative therapies and its impact on medical care and psychological health among children with thalassaemia in Sri Lanka
}

\author{
*Sachith Mettananda ${ }^{1,2}$, Hashan Pathiraja ${ }^{1}$, Ravindu Peiris ${ }^{1}$, Dayananda Bandara ${ }^{3}$, Udaya de Silva ${ }^{4}$, \\ Chamila Mettananda ${ }^{5}$, Anuja Premawardhena ${ }^{2,6}$
}

Sri Lanka Journal of Child Health, 2022; 51(1): 84-91

DOI: http://dx.doi.org/10.4038/sljch.v51i1.10001

\begin{abstract}
Background: $\beta$-thalassaemia is an inherited disorder of haemoglobin synthesis which results in severe transfusion-dependent anaemia from infancy. Although considered a life-limiting disease, it can be cured by allogeneic haematopoietic stem cell transplantation and gene therapy. However, many patients and their families in developing countries are unaware of these treatment options.
\end{abstract}

Objectives: To assess the maternal knowledge on curative therapies and to determine its association with the adequacy of current medical treatment and psychological health among children with $\beta$ thalassaemia.

Method: We conducted a cross-sectional study at the three largest thalassaemia centres of Sri Lanka. All patients with transfusion-dependent $\beta$ thalassaemia aged 2-18 years were eligible for the study. Data were collected using an intervieweradministered questionnaire by interviewing mothers and from medical records. The questionnaire contained questions to gather information on sociodemographic background, clinical details and maternal knowledge on curative therapies for thalassaemia. The psychological morbidity of children was assessed using the previously validated

${ }^{1}$ Department of Paediatrics, Faculty of Medicine, University of Kelaniya, Sri Lanka, ${ }^{2}$ Colombo North Teaching Hospital, Ragama, Sri Lanka, ${ }^{3}$ Kurunegala Teaching Hospital, Sri Lanka, ${ }^{4}$ Anuradhapura Teaching Hospital, Sri Lanka, ${ }^{5}$ Department of Pharmacology, Faculty of Medicine, University of Kelaniya, Sri Lanka, ${ }^{6}$ Department of Medicine, Faculty of Medicine, University of Kelaniya, Sri Lanka

*Correspondence: sachithmetta@yahoo.com

(iD)

https//orcid.org/ 0000-0002-0760-0418

(Received on 14 April 2021: Accepted after revision on 21 May 2021)

The authors declare that there are no conflicts of interest

Personal funding was used for the project.

Open Access Article published under the Creative Commons Attribution CC-BY (c) (i) License 'strengths and difficulties questionnaire'. Binary logistic regression was used in the analysis.

Results: A total of 304 patients (mean age 9.8years; females $54 \%$ ) were recruited. A majority $(86 \%)$ of mothers knew that $\beta$-thalassaemia can be cured by haematopoietic stem cell transplantation; however, only $1 \%$ were aware of gene therapy. Detailed knowledge on curative therapies was lacking in most mothers; only $22 \%$ could identify suitable donors for transplantation. Maternal knowledge on curative therapies was associated with higher educational level and income of parents. Accurate maternal knowledge on haematopoietic stem cell transplantation was significantly associated with lower rates of hepatomegaly, splenomegaly, emotional symptoms, conduct symptoms, hyperactive symptoms and abnormal peer relationships in patients.

Conclusions: This study demonstrated that maternal knowledge on curative therapies among patients with $\beta$-thalassaemia is sub-optimal. It further demonstrated that having an accurate maternal knowledge is associated with improved medical care and a lower prevalence of psychological symptoms among patients.

(Keywords: Bone marrow transplantation, Haematopoietic stem cell transplantations, Thalassaemia, Psychological health)

\section{Background}

$\beta$-thalassaemia is an inherited disorder of haemoglobin synthesis which is characterised by profound anaemia in affected individuals ${ }^{1,2}$. All patients with severe disease require regular blood transfusions from late infancy and remain transfusion-dependent for life $^{3}$. Despite regular transfusions, most patients with $\beta$-thalassaemia living in low- and middle-income countries experience a poor quality of life and die prematurely during the fourth or fifth decade ${ }^{4}$. Allogeneic Haematopoietic Stem Cell Transplantation (HSCT) is available as a cure for $\beta$-thalassaemia since early $1980 \mathrm{~s}^{5}$. Thus far, over 3000 patients have been cured by this procedure worldwide 6 . However, the usefulness of allogeneic HSCT has been limited by its cost, lack of suitable donors and the risk of graft versus host disease ${ }^{7}$. Despite this, it is considered as 
the first-line treatment for patients with TransfusionDependent Beta-Thalassaemia (TDBT) who have Human Leucocyte Antigen (HLA) matched-sibling donors $^{8}$. Gene therapy has emerged as a cure for $\beta$ thalassaemia during recent years ${ }^{9}$. A large clinical trial that involved 22 patients who were successfully treated by gene therapy was published recently ${ }^{10}$. Additionally, several promising new genome editing approaches that aim to correct the $\beta$-globin mutation, upregulate $\gamma$-globin production or downregulate $\alpha$-globin synthesis have entered clinical trials or are in late-stage preclinical studies ${ }^{11-16}$. It is likely that these therapies will supplement HSCT to provide a permanent cure for patients with $\beta$ thalassaemia in the future.

Sri Lanka is a low-middle income country in South Asia with a population of 22 million. Being in a thalassaemia high prevalent tropical region, the gene frequency of $\beta$-thalassaemia in Sri Lanka is reported as $2.8 \%{ }^{17}$. Consequently, there are approximately 1800 patients with TDBT receiving supportive treatment in the country ${ }^{18}$. HSCT transplantation for $\beta$-thalassaemia was commenced in Sri Lanka in 2014; however, it is available only at a limited number of centres ${ }^{19}$. Due to the limitations in availability and cost, HSCT is not routinely considered as a treatment option for patients with TDBT in many developing countries ${ }^{20}$. This is despite some of them having suitable donors. With the recent advances in HSCT and gene therapy, it is important that all patients with $\beta$-thalassaemia and their parents have accurate knowledge on the availability, process, complications, and cost of curative therapies. Also, this knowledge will aid parents to understand the disease and its prognosis better and facilitate making informed decisions. Similarly, it could have a positive impact on adherence to current treatment regimens and the quality of life.

\section{Objectives}

To assess the maternal knowledge on curative therapies and to determine its association with the adequacy of current medical treatment and psychological health of children with $\beta$ thalassaemia.

\section{Method}

We conducted a cross-sectional study at the three largest thalassaemia centres of Sri Lanka located in Kurunegala, Anuradhapura and Ragama Teaching Hospitals. All patients with TDBT aged 2 to 18 years attending these centres from January to March 2018 were eligible to participate in study. Diagnosis of $\beta$ thalassaemia was based on the haemoglobin subtype quantification, and transfusion dependency was defined as requiring blood transfusions more frequently than 6 -weekly. This group represented over $60 \%$ of paediatric patients with TDBT in Sri
Lanka. Children attending without their mothers were excluded.

Data were collected using an intervieweradministered questionnaire by interviewing mothers and going through medical records. First section of the questionnaire contained questions on sociodemographic background, blood transfusion history, presence of hepatomegaly or splenomegaly, average pre-transfusion haemoglobin and iron overload status. Second section of the questionnaire contained questions to assess maternal knowledge on curative treatment options for thalassaemia. These included questions to assess mother's awareness of HSCT and gene therapy as a cure for $\beta$-thalassaemia and detailed knowledge on HSCT, for example, most suitable donor, cost and complications of HSCT. Final section of the questionnaire contained the previously validated Strengths and Difficulties Questionnaire, which measured the psychological health of children in five domains; emotional, conduct, hyperactivity, peer relationships and prosocial behaviour ${ }^{21}$

Sufficiency of supportive medical treatment was determined by the adequacy of blood transfusions and the iron overload status. Adequate transfusion therapy was demonstrated by pre-transfusion haemoglobin greater than $9 \mathrm{~g} / \mathrm{dL}$ and absence of hepatomegaly and splenomegaly. A serum ferritin value below $1000 \mathrm{ng} / \mathrm{mL}$ indicated adequate iron chelation $^{22}$. 'Accurate knowledge on HSCT' was defined as precisely knowing the most suitable donor for HSCT.

Ethical Issues: Study was conducted in accordance with the regulations of the Declaration of Helsinki, and ethical approval was obtained from the Ethics Review Committee of the University of Kelaniya, Sri Lanka (No. P/178/07/2017). Mothers of all eligible patients were briefed about the study, and informed written consent from mothers and assent from children over 12 years were obtained before recruiting into the study.

Statistical analysis: Data were analysed using IBM SPSS statistics 22.0 for Windows. Categorical data were expressed as frequencies and percentages. Binary logistic regression was used to determine associations between categorical variables, and both unadjusted and adjusted odds ratios were presented. Cut-off for statistical significance was set at $\mathrm{p}<0.05$.

\section{Results}

Three hundred and four children with $\beta$ thalassaemia were recruited. Mean age was $9.8 \pm 4.1$ years. Clinical characteristics of study population are shown in Table 1. 
Table 2 shows the maternal knowledge on the curative therapies for thalassaemia.

Table 3 shows the determinants of maternal knowledge on curative therapies for thalassaemia. Age, sex, or type of thalassaemia of the child did not have a significant association with the maternal knowledge on a cure for thalassaemia. However, maternal knowledge on a cure was significantly associated with a higher education level of the mother and father. Similarly, a greater proportion of mothers from families with a high monthly income knew that thalassaemia has a cure compared to mothers from lower-income families.

Table 4 shows the association between maternal knowledge on curative therapies and adequacy of medical treatment. There was no significant association between mother knowing about a cure for thalassaemia and adequacy of current medical treatment. However, a significantly lower proportion of children of mothers with an 'accurate knowledge on HSCT' as defined by accurately knowing the best donor for HSCT had hepatomegaly and splenomegaly. Finally, we hypothesised that an improved maternal knowledge on curative therapies for thalassaemia might have a favourable impact on the psychological health among patients.

Table 5 shows the association between maternal knowledge on curative therapies and the psychological health of their children. This revealed that children of mothers who knew about a cure for thalassaemia had a significantly lower prevalence of emotional symptoms $(\mathrm{p}<0.05)$ and abnormal peer relationships $\quad(p<0.05)$. Similarly, 'accurate knowledge on HSCT' in mothers was significantly associated with a lower rate of emotional symptoms $(p<0.01)$, conduct symptoms $(p<0.01)$, hyperactive symptoms $(\mathrm{p}<0.01)$ and abnormal peer relationships $(\mathrm{p}<0.05)$ among children

Table 1

\begin{tabular}{|c|c|}
\hline Characteristic & n (\%) \\
\hline $\begin{array}{l}\text { Type of thalassaemia } \\
\beta \text {-Thalassaemia major } \\
\text { Haemoglobin E } \beta \text {-thalassaemia } \\
\text { Other }\end{array}$ & $\begin{array}{l}255(83.9) \\
46(15.1) \\
03(01.0)\end{array}$ \\
\hline $\begin{array}{l}\text { Sex } \\
\text { Male } \\
\text { Female }\end{array}$ & $\begin{array}{l}139(45.7) \\
165(54.3)\end{array}$ \\
\hline $\begin{array}{l}\text { Age group } \\
2-4 \text { years } \\
5-12 \text { years } \\
13-18 \text { years }\end{array}$ & $\begin{array}{l}40(13.2) \\
183(60.2) \\
81(26.6)\end{array}$ \\
\hline $\begin{array}{l}\text { Average pre-transfusion } \mathrm{Hb} \\
<9 \mathrm{~g} / \mathrm{dL} \\
\geq 9 \mathrm{~g} / \mathrm{dL}\end{array}$ & $\begin{array}{l}185(60.8) \\
119(39.1)\end{array}$ \\
\hline $\begin{array}{l}\text { Liver status } \\
\text { No hepatomegaly } \\
\text { Hepatomegaly }\end{array}$ & $\begin{array}{c}210(69.1) \\
94(30.9)\end{array}$ \\
\hline $\begin{array}{l}\text { Spleen status } \\
\text { No splenomegaly } \\
\text { Splenomegaly } \\
\text { Splenectomised }\end{array}$ & $\begin{array}{l}199(65.5) \\
98(32.3) \\
07(02.3)\end{array}$ \\
\hline $\begin{array}{l}\text { Serum ferritin* } \\
\leq 1000 \mathrm{ng} / \mathrm{mL} \\
>1000 \mathrm{ng} / \mathrm{mL}\end{array}$ & $\begin{array}{c}97(31.9) \\
196(64.5)\end{array}$ \\
\hline $\begin{array}{l}\text { Psychological symptoms } \\
\text { Emotional symptoms } \\
\text { Conduct symptoms } \\
\text { Hyperactivity symptoms } \\
\text { Abnormal peer relationships } \\
\text { Abnormal social behaviour }\end{array}$ & $\begin{array}{l}55(18.1) \\
57(18.8) \\
29(09.5) \\
45(14.8) \\
08(02.6)\end{array}$ \\
\hline
\end{tabular}

* Data missing from 11 subjects; Hb: haemoglobin

Table 2: Maternal knowledge on curative therapies for $\beta$-thalassaemia $(n=304)$

\begin{tabular}{|c|c|}
\hline Characteristic & Frequency $(\%)$ \\
\hline $\begin{array}{l}\text { Knowledge on curative therapies for thalassaemia } \\
\text { Knew that thalassaemia has a cure } \\
\text { Knew that HSCT is a cure for thalassaemia } \\
\text { Knew that gene therapy is an experimental cure }\end{array}$ & $\begin{array}{c}263(86.5) \\
262(86.2) \\
03(01.0)\end{array}$ \\
\hline $\begin{array}{l}\text { Detailed knowledge of HSCT } \\
\text { Accurately knew the cost of HSCT } \\
\text { Accurately knew the best donor for HSCT } \\
\text { Knew parents can donate HSC } \\
\text { Knew HLA-matched non-relatives can donate HSC } \\
\text { Knew cord blood can be a source of HSC } \\
\text { Knew graft failure is a complication of HSCT } \\
\text { Knew HSCT has an associated mortality }\end{array}$ & $\begin{array}{c}62(20.4) \\
69(22.7) \\
273(88.8) \\
138(45.4) \\
01(0.3) \\
45(14.8) \\
33(10.9)\end{array}$ \\
\hline $\begin{array}{l}\text { Consideration of HSCT as a cure for their child } \\
\text { Medical staff has discussed HSCT } \\
\text { Child has been offered a chance for evaluation for HSCT } \\
\text { HLA typing has been done } \\
\text { Child is awaiting HSCT }\end{array}$ & $\begin{array}{l}254(83.6) \\
177(58.2) \\
80(26.3) \\
11(03.6)\end{array}$ \\
\hline
\end{tabular}

HSCT: Haematopoietic stem cell transplantation, HSC: Haematopoietic stem cells, HLA: Human leucocyte antigen 
Table 3: Determinants of maternal knowledge on curative therapies for thalassaemia

\begin{tabular}{|c|c|c|c|c|c|}
\hline Characteristic & $\begin{array}{l}\text { Mothers knowing } \\
\text { thalassaemia has a } \\
\text { cure n }(\%)\end{array}$ & $\begin{array}{l}\text { Mothers not knowing } \\
\text { thalassaemia has a } \\
\text { cure } n(\%)\end{array}$ & $\begin{array}{l}\text { Unadjusted } \\
\text { odds ratio } \\
(95 \% \mathrm{CI})\end{array}$ & $\begin{array}{l}\text { Adjusted } \\
\text { odds ratio } \\
(95 \% C I\end{array}$ & p-value \\
\hline $\begin{array}{l}\text { Sex of the child } \\
\text { Male }(\mathrm{n}=139) \\
\text { Female }(\mathrm{n}=165)\end{array}$ & $\begin{array}{l}118(84.9) \\
145(87.9) \\
\end{array}$ & $\begin{array}{l}21(15.1) \\
20(12.1) \\
\end{array}$ & $\begin{array}{c}0.77 \\
(0.40-1.49) \\
\end{array}$ & $\begin{array}{c}0.79 \\
(0.40-1.53) \\
\end{array}$ & 0.48 \\
\hline $\begin{array}{l}\text { Type of thalassaemia } \\
\text { Thalassaemia major }(\mathrm{n}=255) \\
\text { HbE thalassaemia and other }(\mathrm{n}=49)\end{array}$ & $\begin{array}{r}221(86.7) \\
42(85.7)\end{array}$ & $\begin{array}{l}34(13.3) \\
07(14.3)\end{array}$ & $\begin{array}{c}1.08 \\
(0.45-2.60)\end{array}$ & $\begin{array}{c}1.04 \\
(0.43-2.51)\end{array}$ & 0.93 \\
\hline $\begin{array}{l}\text { Mother's educational level } \\
\text { Above grade } 10(\mathrm{n}=99) \\
\text { Grade } 10 \text { or below }(\mathrm{n}=205)\end{array}$ & $\begin{array}{c}92(92.9) \\
171(83.4)\end{array}$ & $\begin{array}{l}07(07.1) \\
34(16.6)\end{array}$ & $\begin{array}{c}2.61 \\
(1.11-6.12)\end{array}$ & $\begin{array}{c}2.60 \\
(1.10-6.11)\end{array}$ & $<0.05$ \\
\hline $\begin{array}{l}\text { Father's educational level } \\
\text { Above grade } 10(\mathrm{n}=78) \\
\text { Grade } 10 \text { or below }(\mathrm{n}=226)\end{array}$ & $\begin{array}{c}75(96.2) \\
188(83.2)\end{array}$ & $\begin{array}{l}03(03.8) \\
38(16.8)\end{array}$ & $\begin{array}{c}5.05 \\
(1.51-16.8)\end{array}$ & $\begin{array}{c}5.04 \\
(1.50-16.8)\end{array}$ & $<0.01$ \\
\hline $\begin{array}{l}\text { Mother's occupation } \\
\text { Employed }(\mathrm{n}=44) \\
\text { Unemployed }(\mathrm{n}=260)\end{array}$ & $\begin{array}{c}39(88.6) \\
224(86.2)\end{array}$ & $\begin{array}{l}05(11.4) \\
36(13.8)\end{array}$ & $\begin{array}{c}1.25 \\
(0.46-3.39)\end{array}$ & $\begin{array}{c}1.29 \\
(0.47-3.54)\end{array}$ & 0.60 \\
\hline $\begin{array}{l}\text { Father's occupation } \\
\text { Skilled or professional }(\mathrm{n}=99) \\
\text { Unskilled }(\mathrm{n}=205)\end{array}$ & $\begin{array}{c}91(91.9) \\
172(83.9)\end{array}$ & $\begin{array}{l}08(08.1) \\
33(16.1)\end{array}$ & $\begin{array}{c}2.18 \\
(0.96-4.92)\end{array}$ & $\begin{array}{c}2.16 \\
(0.95-4.89)\end{array}$ & 0.06 \\
\hline $\begin{array}{l}\text { Monthly family income } \\
>\text { LKR } 25000(\mathrm{n}=101) \\
\leq \text { LKR } 25000(\mathrm{n}=202)\end{array}$ & $\begin{array}{c}93(92.1) \\
169(83.7)\end{array}$ & $\begin{array}{l}08(07.9) \\
33(16.3)\end{array}$ & $\begin{array}{c}2.27 \\
(1.00-5.11)\end{array}$ & $\begin{array}{c}2.31 \\
(1.01-5.25)\end{array}$ & $<0.05$ \\
\hline
\end{tabular}

LKR: Sri Lankan rupees, CI: confidence interval

Table 4: Association between maternal knowledge on curative therapies and adequacy of medical care

\begin{tabular}{|c|c|c|c|c|c|}
\hline Maternal knowledge & $\begin{array}{c}\text { Sub-optimal } \\
\text { pre-transfusion } \\
\mathrm{Hb}<\mathbf{g} / \mathbf{d L} \\
(\mathbf{n}=185)\end{array}$ & $\begin{array}{c}\text { Optimal pre- } \\
\text { transfusion } \mathrm{Hb} \\
\geq 9 \mathrm{~g} / \mathrm{dL} \\
(\mathrm{n}=119)\end{array}$ & $\begin{array}{l}\text { Unadjusted } \\
\text { odds ratio } \\
(95 \% \mathrm{CI})\end{array}$ & $\begin{array}{l}\text { Adjusted odds } \\
\text { ratio }(95 \% \mathrm{CI})\end{array}$ & p-value \\
\hline Knew about a cure for thalassaemia $n(\%)$ & $160(86.5)$ & $103(86.6)$ & $0.99(0.50-1.95)$ & $0.96(0.47-1.96)$ & 0.91 \\
\hline \multirow[t]{2}{*}{ Accurate knowledge on HSCT n (\%) } & $47(25.4)$ & $22(18.5)$ & $1.50(0.85-2.65)$ & $1.54(0.86-2.76)$ & 0.14 \\
\hline & $\begin{array}{c}\text { Hepatomegaly } \\
(\mathrm{n}=94)\end{array}$ & $\begin{array}{c}\text { No hepatomegaly } \\
(\mathbf{n}=\mathbf{2 1 0})\end{array}$ & & & \\
\hline Knew about a cure for thalassaemia n (\%) & $81(86.2)$ & $182(86.7)$ & $0.95(0.47-1.94)$ & $1.50(0.69-3.22)$ & 0.29 \\
\hline \multirow{2}{*}{ Accurate knowledge on HSCT n (\%) } & $10(10.6)$ & $59(28.1)$ & $0.30(0.14-0.62)$ & $0.30(0.14-0.64)$ & $<0.01$ \\
\hline & $\begin{array}{c}\text { Splenomegaly } \\
(\mathrm{n}=98\end{array}$ & $\begin{array}{c}\text { No splenomegaly } \\
(n=206)\end{array}$ & & & \\
\hline \multirow[t]{2}{*}{$\begin{array}{l}\text { Knew about a cure for thalassaemia n (\%) } \\
\text { Accurate knowledge on HSCT n (\%) }\end{array}$} & $\begin{array}{l}84(85.7) \\
07(07.1)\end{array}$ & $\begin{array}{c}179(86.9) \\
62(30.1)\end{array}$ & $\begin{array}{l}0.90(0.45-1.81) \\
0.17(0.07-0.40)\end{array}$ & $\begin{array}{l}1.45(0.69-3.08) \\
0.17(0.07-0.41)\end{array}$ & $\begin{array}{c}0.32 \\
<0.001\end{array}$ \\
\hline & $\begin{array}{c}\text { Sub-optimal } \\
\text { SF }>1000 \mathrm{ng} / \mathrm{mL} \\
(\mathrm{n}=196)\end{array}$ & $\begin{array}{c}\text { Optimal } \\
\mathrm{SF} \leq 1000 \mathrm{ng} / \mathrm{mL} \\
(\mathrm{n}=97)\end{array}$ & & & \\
\hline Knew about a cure for thalassaemia n (\%) & $172(87.8)$ & $83(85.6)$ & $1.20(0.59-2.45)$ & $1.01(0.47-2.15)$ & 0.32 \\
\hline Accurate knowledge on HSCT n (\%) & $53(27.0)$ & $14(14.4)$ & $2.19(1.14-4.20)$ & $2.18(1.12-4.21)$ & $<0.05$ \\
\hline
\end{tabular}

HSCT: Haematopoietic stem cell transplantation, Hb: Haemoglobin, SF: Serum ferritin, CI: confidence interval

Table 5: Association between maternal knowledge on curative therapies and psychological health of their children

\begin{tabular}{|c|c|c|c|c|c|}
\hline Maternal knowledge & \begin{tabular}{|c}
$\begin{array}{c}\text { Emotional symptoms } \\
(\mathrm{n}=55)\end{array}$ \\
\end{tabular} & $\begin{array}{c}\text { No emotional } \\
\text { symptoms }(n=249)\end{array}$ & $\begin{array}{l}\text { Unadjusted odds } \\
\text { ratio }(95 \% \mathrm{CI})\end{array}$ & $\begin{array}{l}\text { Adjusted odds } \\
\text { ratio }(95 \% \mathrm{CI})\end{array}$ & $\begin{array}{c}\text { p- } \\
\text { value }\end{array}$ \\
\hline \multirow{3}{*}{$\begin{array}{l}\text { Knew about a cure for thalassaemia n (\%) } \\
\text { Accurate knowledge on HSCT n (\%) }\end{array}$} & $42(76.4)$ & $221(88.8)$ & $0.40(0.19-0.85)$ & $0.42(0.19-0.95)$ & $<0.05$ \\
\hline & $01(01.8)$ & $67(27.1)$ & $0.04(0.01-0.36)$ & $0.05(0.01-0.38)$ & $<0.01$ \\
\hline & $\begin{array}{c}\text { Conduct symptoms } \\
(\mathrm{n}=\mathbf{5 7})\end{array}$ & $\begin{array}{c}\text { No conduct } \\
\text { symptoms }(n=247)\end{array}$ & & & \\
\hline \multirow{3}{*}{$\begin{array}{l}\text { Knew about a cure for thalassaemia n (\%) } \\
\text { Accurate knowledge on HSCT n (\%) }\end{array}$} & $46(80.7)$ & $217(87.9)$ & $0.57(0.27-1.23)$ & $0.76(0.34-1.71)$ & 0.51 \\
\hline & $02(03.5)$ & $67(27.1)$ & $0.09(0.02-0.41)$ & $0.10(0.02-0.43)$ & $<0.01$ \\
\hline & $\begin{array}{c}\text { Hyperactivity } \\
\text { symptoms }(n=29)\end{array}$ & $\begin{array}{c}\text { No hyperactivity } \\
\text { symptoms } \\
(n=275)\end{array}$ & & & \\
\hline \multirow{3}{*}{$\begin{array}{l}\text { Knew about a cure for thalassaemia n (\%) } \\
\text { Accurate knowledge on HSCT n (\%) }\end{array}$} & $24(82.8)$ & $239(86.9)$ & $0.72(0.25-2.01)$ & $1.01(0.34-3.00)$ & 0.97 \\
\hline & 0 & $69(25.1)$ & & & $<0.01^{*}$ \\
\hline & $\begin{array}{l}\text { Abnormal peer } \\
\text { relationships }(n=45)\end{array}$ & $\begin{array}{c}\text { Normal peer } \\
\text { relationships } \\
(\mathrm{n}=259)\end{array}$ & & & \\
\hline \multirow{3}{*}{$\begin{array}{l}\text { Knew about a cure for thalassaemia n (\%) } \\
\text { Accurate knowledge on HSCT n (\%) }\end{array}$} & $29(64.4)$ & $234(90.3 \%)$ & $0.19(0.09-0.40)$ & $0.35(0.15-0.77)$ & $<0.05$ \\
\hline & $01(02.2)$ & $68(26.3 \%)$ & $0.06(0.01-0.47)$ & $0.09(0.01-0.69)$ & $<0.05$ \\
\hline & $\begin{array}{c}\text { Abnormal social } \\
\text { behaviour } \\
(\mathrm{n}=8)\end{array}$ & $\begin{array}{c}\text { Normal social } \\
\text { behaviour } \\
(\mathrm{n}=296)\end{array}$ & & & \\
\hline Knew about a cure for thalassaemia n (\%) & $07(87.5)$ & $256(86.5)$ & $1.09(0.13-9.12)$ & $0.81(0.08-7.86)$ & 0.85 \\
\hline Accurate knowledge on HSCT n (\%) & $03(37.5)$ & $66(22.3)$ & $2.09(0.48-8.97)$ & $2.10(0.46-9.53)$ & 0.33 \\
\hline
\end{tabular}

* Chi-square test 


\section{Discussion}

In this paper, we presented the findings of one of the largest studies assessing maternal knowledge on curative therapies among paediatric patients with TDBT. The study included 304 children, which comprised over $60 \%$ of the paediatric population with TDBT in Sri Lanka. Also, we evaluated the association between maternal knowledge on curative therapies on current medical treatment and psychological health among children with thalassaemia. We found that maternal knowledge on curative therapies in the study population was relatively low. Although $86 \%$ of parents knew that thalassaemia could be cured by HSCT, a very low proportion of them had the appropriate in-depth knowledge of the procedure. Only one-fifth knew that the HLA-matched sibling is the most suitable donor for HSCT, and a similar proportion accurately knew the cost of the procedure. Importantly only $1 \%$ recognised gene therapy as a developing cure. Less than half were aware of the fact that unrelated HLAmatched individual could be the donor, and less than $1 \%$ knew that cord blood could be used as a source of HSCs. These low figures were not expected in a country with a high literacy rate and easy and free access to health care like Sri Lanka. Specifically, this reflects the lack of enthusiasm and commitment among the medical teams providing the necessary knowledge to the patients. This is further reflected by the fact that only one-fourth of these children have undergone HLA-typing.

As expected, higher educational level in mother and father, as well as higher income, were associated with maternal knowledge on curative therapies of thalassaemia. Similar findings were reported by studies from the same region. For example, Manzoor $\mathrm{I}$, et al reported poor parental knowledge of screening services for thalassaemia major among mothers who were housewives, had a lower education level and had lower family income ${ }^{23}$. One important finding of our study is that having an accurate knowledge on HSCT was associated with a lower prevalence of hepatomegaly and splenomegaly. This is important as hepatomegaly and splenomegaly indicate worsening of extramedullary haematopoiesis and sub-optimal blood transfusions ${ }^{24}$. Thus, knowledge on curative therapies seems to generate hopes for a cure in these patients, which has possibly motivated them to obtain blood transfusions on time. Our results correspond with the findings of a study on $\beta$ thalassaemia patients in Taiwan, which reported a positive association between knowledge about the disease and treatment adherence ${ }^{25}$.

The most significant finding of our study is the report of a significantly lower prevalence of psychological symptoms among children of parents with accurate knowledge on curative therapies. This clearly shows that a better understanding of the disease and knowledge on the availability of a cure by the family is psychologically advantageous to children with thalassaemia, even if they do not have plans to undergo these procedures in the near future. This is especially important as patients with thalassaemia are reported to have a higher prevalence of psychological symptoms than the normal population ${ }^{26}$. As our study recruited over half of the paediatric thalassaemic population of Sri Lanka, the results are generalisable to the entire country. Similarly, the three study sites are situated in three discrete provinces and function as tertiary referral centres for the entire country, further improving the validity of the study. Also, $\beta$ thalassaemia is a rare disease globally; thus, a study involving over 300 participants of the disease is not easy to perform anywhere in the world ${ }^{27}$. Considering the scale of the study, our results would be useful to guide education, assessment, and management of patients with $\beta$-thalassaemia globally.

One important limitation of the study is that we only looked at maternal knowledge and did not evaluate the knowledge of patients themselves. Patient knowledge and attitude is an important factor in predicting the outcome and quality of life in chronic diseases, especially among older children ${ }^{28}$. Also, our study did not involve fathers. However, this may not have a major impact as in the cultural context of Sri Lanka, care for a sick child is mainly provided by mothers, and the female literacy rate in the country is over $90 \%$, which is comparable to that of males. Based on the results of the study we recommend that all children with thalassaemia and their families are provided with current, accurate and up-to-date information on curative therapies which are available or in the development.

\section{Conclusions}

This study demonstrated that maternal knowledge on curative therapies among patients with $\beta$ thalassaemia is sub-optimal. It further demonstrated that having an accurate maternal knowledge is associated with improved medical care and a lower prevalence of psychological symptoms among patients.

\section{References}

1. Taher AT, Weatherall DJ, Cappellini MD. Thalassaemia. Lancet 2018; 391(10116): 155-67. https://doi.org/10.1016/S01406736(17)318 22-6

2. Mettananda S, Higgs DR. Molecular basis and genetic modifiers of thalassaemia. 
Hematology/Oncology Clinics of North America. 2018; 32(2): 177-91.

https://doi.org/10.1016/j.hoc.2017.11.003

PMid: 29458725

3. Mettananda S. Management of thalassaemia. Sri Lanka Journal of Child Health 2018; 47(2): 159-65.

https://doi.org/10.4038/sljch.v47i2.8484

4. Mettananda S, Pathiraja $\mathrm{H}$, Peiris $\mathrm{R}$, Bandara D, de Silva U, Mettananda C, et al. Health related quality of life among children with transfusion dependent betathalassaemia major and haemoglobin $\mathrm{E}$ beta-thalassaemia in Sri Lanka: a case control study. Health and Quality of Life Outcomes 2019; 17(1): 137. https://doi.org/10.1186/s12955-019-12079

PMid: 31395066 PMCid: PMC6686351

5. Angelucci E, Matthes-Martin S, Baronciani D, Bernaudin F, Bonanomi S, Cappellini MD, et al. Hematopoietic stem cell transplantation in thalassemia major and sickle cell disease: indications and management recommendations from an international expert panel. Haematologica 2014; 99(5): 811-20.

https://doi.org/10.3324/haematol.2013.099 747

PMid: 24790059 PMCid: PMC4008115

6. Baronciani D, Angelucci E, Potschger U, Gaziev J, Yesilipek A, Zecca M, et al. Hemopoietic stem cell transplantation in thalassemia: a report from the European Society for Blood and Bone Marrow Transplantation Hemoglobinopathy Registry, 2000-2010. Bone marrow transplantation 2016; 51(4): 536-41. https://doi.org/10.1038/bmt.2015.293 PMid: 26752139

7. El-Beshlawy A, El-Ghamrawy M. Recent trends in treatment of thalassaemia. Blood Cells, Molecules \& Diseases 2019; 76: 538. https://doi.org/10.1016/j.bcmd.2019.01.00 6

PMid: 30792169

8. Cappellini MD, Cohen A, Porter J, Taher A, Viprakasit V. Guidelines for the management of transfusion dependent thalassaemia (TDT) 3rd Edition ed. Cappellini MD, Cohen A, Porter J, Taher A, Viprakasit V, editors. Cyprus:
Thalassaemia International Federation; 2014.

9. Ghiaccio V, Chappell M, Rivella S, Breda L. Gene therapy for BetaHemoglobinopathies: Milestones, New Therapies and Challenges. Molecular Diagnosis and Therapy 2019; 23(2): 17386. https://doi.org/10.1007/s40291-019003834

PMid: 30701409

10. Thompson AA, Walters MC, Kwiatkowski J, Rasko JEJ, Ribeil JA, Hongeng S, et al. Gene therapy in patients with transfusiondependent beta-thalassemia. New England Journal of Medicine 2018; 378(16): 147993.

https://doi.org/10.1056/NEJMoa1705342 PMid: 29669226

11. Canver MC, Smith EC, Sher F, Pinello L, Sanjana NE, Shalem O, et al. BCL11A enhancer dissection by Cas9-mediated in situ saturating mutagenesis. Nature 2015; 527(7577):192-7.

https://doi.org/10.1038/nature15521

PMid: 26375006 PMCid: PMC4644101

12. Mettananda S, Yasara N, Fisher CA, Taylor S, Gibbons R, Higgs D. Synergistic silencing of alpha-globin and induction of gamma-globin by histone deacetylase inhibitor, vorinostat as a potential therapy for beta-thalassaemia. Scientific Reports 2019; 9(1): 11649.

https://doi.org/10.1038/s41598-01948204-2

PMid: 31406232 PMCid: PMC6690964

13. Mettananda S, Fisher CA, Hay D, Badat M, Quek L, Clark K, et al. Editing an alphaglobin enhancer in primary human hematopoietic stem cells as a treatment for beta-thalassemia. Nature Communications 2017; 8(1): 424.

https://doi.org/10.1038/s41467-01700479-7

PMid: 28871148 PMCid: PMC5583283

14. Mettananda S. Thalassaemia: In a quest towards an ultimate cure. Sri Lanka Journal of Child Health 2017; 46(3): 20310.

https://doi.org/10.4038/sljch.v46i3.8318 
15. Yasara N, Wickramarathne N, Mettananda C, Manamperi A, Premawardhena A, Mettananda S. Efficacy and safety of oral hydroxyurea in transfusion-dependent $\beta$ thalassaemia: a protocol for randomised double-blind controlled clinical trial. $B M J$ Open 2020; 10(10): e041958.

https://doi.org/10.1136/bmjopen-2020041958

PMid: 33109679 PMCid: PMC7592299

16. Mettananda S, Fisher CA, Sloane-Stanley JA, Taylor S, Oppermann U, Gibbons RJ, et al. Selective silencing of alpha-globin by the histone demethylase inhibitor IOX1: a potentially new pathway for treatment of beta-thalassemia. Haematologica 2017; 102(3): e80-e4.

https://doi.org/10.3324/haematol.2016.155 655

PMid: 27810991 PMCid: PMC5394973

17. Mettananda S, de Silva DG. Anaemia in children: are we using the correct prevention strategies? Ceylon Medical Journal 2017; 62(2): 73-6.

https://doi.org/10.4038/cmj.v62i2.8469

PMid: 28697539

18. Premawardhana AP, Mudiyanse R, De Silva ST, Jiffry N, Nelumdeniya U, de Silva U, et al. A nationwide survey of hospital-based thalassemia patients and standards of care and a preliminary assessment of the national prevention program in Sri Lanka. PloS One 2019; 14(8): e0220852.

https://doi.org/10.1371/journal.pone.0220 852

PMid: 31419232 PMCid: PMC6697367

19. Mettananda S. Recent developments in the treatment of transfusion dependent thalassaemia. Ceylon Medical Journal 2020; 65(3): 35 .

https://doi.org/10.4038/cmj.v65i3.9183

20. Mettananda S. Thalassaemia: Current research may provide a cure to it in the future. Sri Lanka Journal of Child Health 2018; 47(4): 372.

https://doi.org/10.4038/sljch.v47i4.8606

21. Prior M, Virasinghe S, Smart D. Behavioural problems in Sri Lankan schoolchildren: associations with socioeconomic status, age, gender, academic progress, ethnicity and religion. Social Psychiatry and Psychiatric Epidemiology 2005; 40(8): 654-62. https://doi.org/10.1007/s00127-005-0942$\mathrm{X}$ PMid: 16091856

22. Suriapperuma T, Peiris R, Mettananda C, Premawardhena A, Mettananda S. Body iron status of children and adolescents with transfusion dependent beta-thalassaemia: trends of serum ferritin and associations of optimal body iron control. BMC Research Notes 2018; 11(1):547. https://doi.org/10.1186/s13104-018-36349

PMid: 30071883 PMCid: PMC6071405

23. Manzoor I, Zakar R. Sociodemographic determinants associated with parental knowledge of screening services for thalassemia major in Lahore. Pakistan Journal of Medical Sciences 2019; 35(2): 483-8.

https://doi.org/10.12669/pjms.35.2.613

PMid: 31086537 PMCid: PMC6500821

24. Mettananda S, Pathiraja H, Peiris R, Wickramarathne N, Bandara D, de Silva U, et al. Blood transfusion therapy for betathalassemia major and hemoglobin E betathalassemia: Adequacy, trends, and determinants in Sri Lanka. Pediatric Blood \& Cancer 2019; 66(5): e27643.

https://doi.org/10.1002/pbc.27643

PMid: 30697927

25. Lee YL, Lin DT, Tsai SF. Disease knowledge and treatment adherence among patients with thalassemia major and their mothers in Taiwan. Journal of Clinical Nursing 2009; 18(4): 529-38.

https://doi.org/10.1111/j.13652702.2007.0 2150.x

PMid: 19192002

26. Mettananda S, Peiris R, Pathiraja H, Chandradasa M, Bandara D, de Silva U, et al. Psychological morbidity among children with transfusion dependent betathalassaemia and their parents in Sri Lanka. PloS One 2020; 15(2): e0228733. https://doi.org/10.1371/journal.pone.0228 733

PMid: 32045443 PMCid: PMC7012414

27. Yasara N, Premawardhena A, Mettananda S. A comprehensive review of hydroxyurea for beta-haemoglobinopathies: the role revisited during COVID-19 pandemic. Orphanet Journal of Rare Diseases 2021; 16(1): 114. 
https://doi.org/10.1186/s13023-021-

01757-w

PMid: 33648529 PMCid: PMC7919989

28. Jeesh A, Aser Adnan Y, Al-Haboub MAB. The Effects of Patients' and Care-Givers' Knowledge, Attitude \& Practice (KAP) on Quality of Life Among Thalassemia Major Patients' in Damascus-Syrian Arab Republic. 2018.

https://doi.org/10.19044/esj.2018.v14n12p 308 